\title{
Delivering the Moorgate shaft base slab on Crossraill, UK
}

Adrian Douglas Eur Ing, MEng, CEng, MICE Principal Engineer, Mott MacDonald Ltd, Croydon, UK

Marcus Smith BSC

Construction Manager, Bam Nutall Kier joint venture, UK
Jonathan Hunter BEng, CEng, MICE Site Manager, Crossrail Ltd, UK

The Moorgate shaft at Crossrail Liverpool Street station is one of the deepest in London, UK. Construction of the base slab to the $\mathbf{4 2} \mathrm{m}$ deep shaft required close collaboration between the client, designer, contractor and suppliers to give assurance that the slab was watertight. Dense reinforcement was detailed to ensure ease of fixing within the tight confines of the shaft and allow for the tolerance on the diaphragm walls. The concrete design was developed to ensure that it met the requirements for placing and structural strength while achieving good control on the temperature developed. The concrete mix was trialled for temperature development and initial set to allow relaxation of the original specification. The pour plan was developed with the co-operation of all the site teams to ensure appropriate contingency measures were in place. Temperature monitoring was carried out to ensure that mitigation measures could be applied to control placed concrete temperature against predetermined trigger levels.

\section{Introduction}

Figure 1 shows how the new Crossrail station at Liverpool Street in London, UK extends between the London Underground stations at Liverpool Street and Moorgate. The Moorgate shaft is at the west end and contains part of the main escalator bank from the ticket hall, emergency egress from the station platforms, a fire-fighting lift, a passenger lift, station ventilation, tunnel ventilation, and part of the connection to the London Underground Northern line. The new station's platforms are the deepest below ground level on Crossrail.

The shaft is an irregular shape, approximately $34 \mathrm{~m}$ square in plan, and is $42 \mathrm{~m}$ deep to the bottom of the excavation. The plan

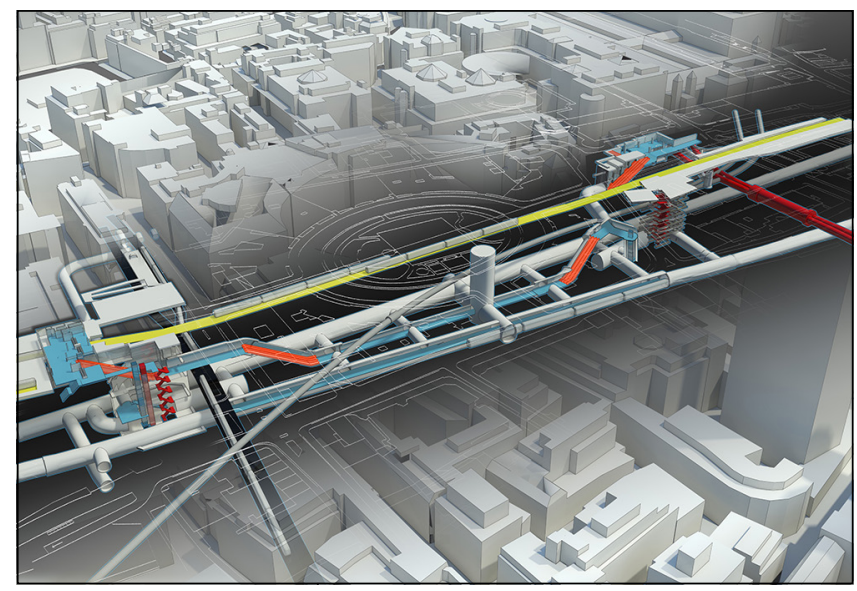

Figure 1. Liverpool Street Crossrail station - Moorgate shaft is on the left at base slab level is shown in Figure 2 and a typical section in Figure 3. A general view looking down the shaft is shown in Figure 4.

This paper describes the design requirements for the base slab at the bottom of the shaft, the detailing of the reinforcement, the planning for the concrete pour, the execution of the pour and the temperature monitoring after the pour. The principal pour parameters are given in Table 1

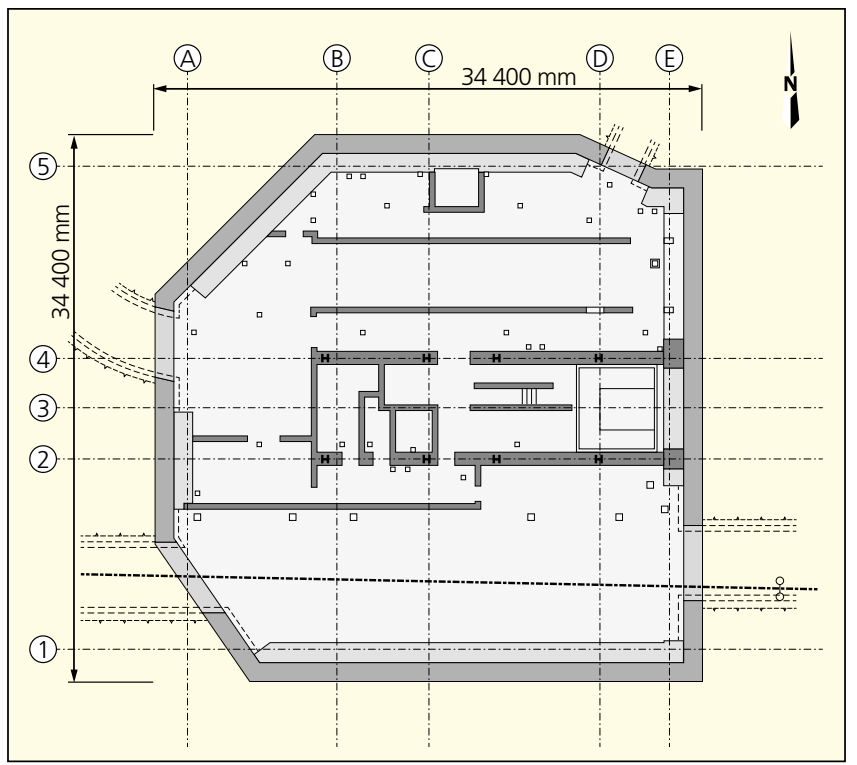

Figure 2. Plan of base slab 


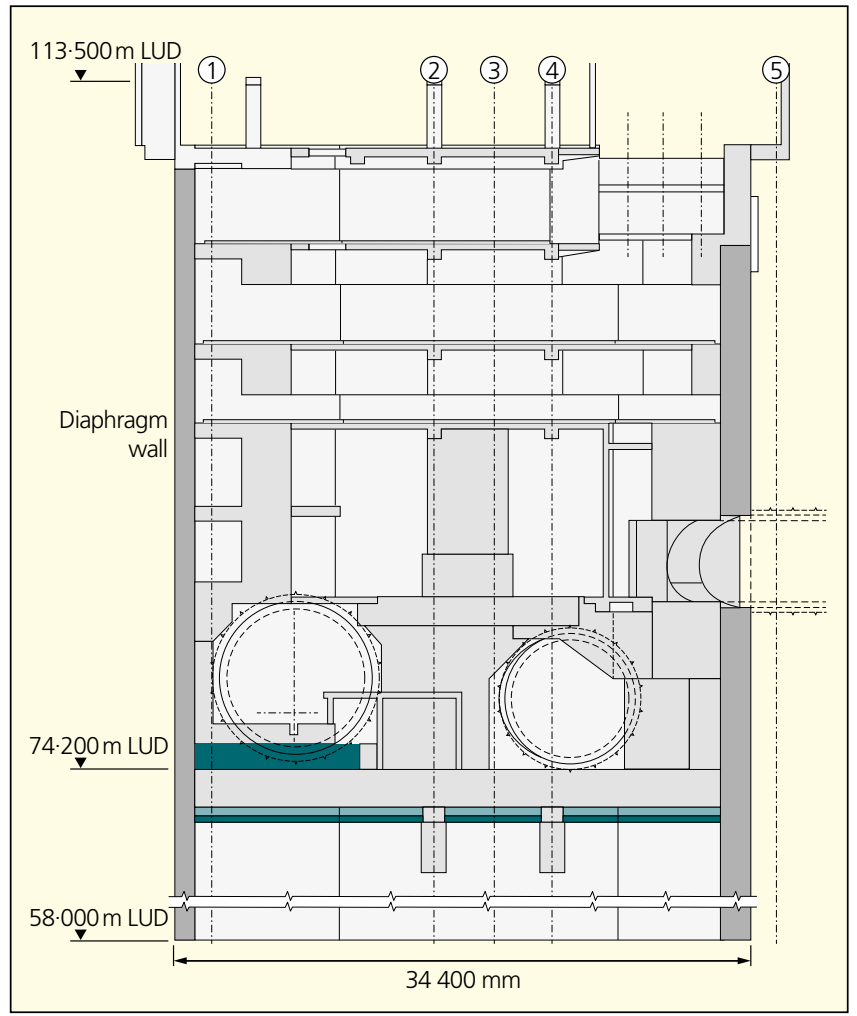

Figure 3. Vertical section through shaft - grid B looking west (m LUD, metres above London Underground datum which is $100 \mathrm{~m}$ below Ordnance datum)

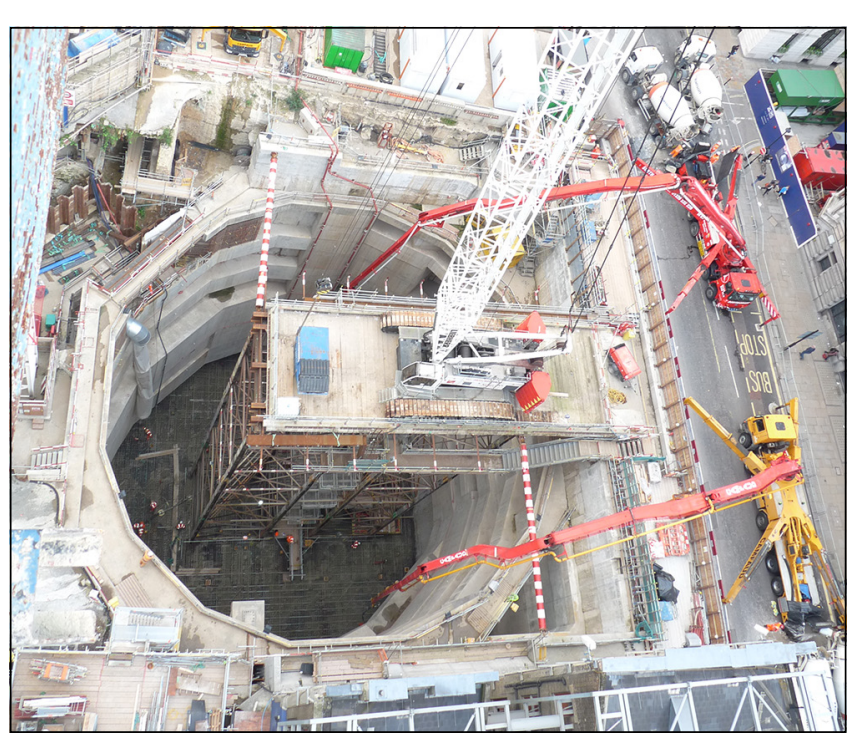

Figure 4. View of shaft and construction access jetty during concrete pour

The shaft was designed by Mott MacDonald as part of the Crossrail design contract $\mathrm{C} 138$. The contractor for the shaft was a joint venture of Bam Nuttall and Kier under the Crossrail enabling works contract C501. The contractor was responsible for detailing the reinforcement from design intent (RIBA stage E) drawings prepared by the designer.

\begin{tabular}{|ll|}
\hline Parameter & Value \\
\hline Concrete C35/45, DC-4, F5 volume & $1750 \mathrm{~m}^{3}$ \\
\hline Reinforcement tonnage & $830 \mathrm{t}$ \\
\hline Number of reinforcement detail drawings & 118 \\
\hline Time to detail drawings & 110 days \\
\hline Time to fix reinforcement & 51 days \\
\hline Time for pour for base slab & $17 \mathrm{~h}$ \\
\hline Peak measured concrete temperature & $55^{\circ} \mathrm{C}$ \\
\hline Maximum measured differential temperature & $30^{\circ} \mathrm{C}$ \\
\hline
\end{tabular}

Table 1. Principal pour parameters

\section{Design}

The shaft was excavated through London Clay into the top of the Lambeth Group. A $300 \mathrm{~mm}$ thick blinding slab was cast onto the ground at the bottom of the excavation to strut the diaphragm walls while the base slab was constructed. The ground beneath the base slab is expected to heave by up to $140 \mathrm{~mm}$. The groundwater is underdrained to the underlying chalk so, although the water table is near ground level, the base slab is only subject to a characteristic water pressure of $270 \mathrm{kPa}$ ( $27 \mathrm{~m}$ head). This was used for design approach 1 combination 2 in accordance with BS EN 1997-1 (BSI, 2004).

A controlled collapsible void former was specified under the slab to limit the load due to ground heave to $75 \mathrm{kPa}$. The $2 \mathrm{~m}$ thick base slab is connected to the perimeter diaphragm wall and central tension barrettes as shown in Figure 5. The slab was designed to be watertight to class 1 to BS EN 1992-3 (BSI, 2006a).

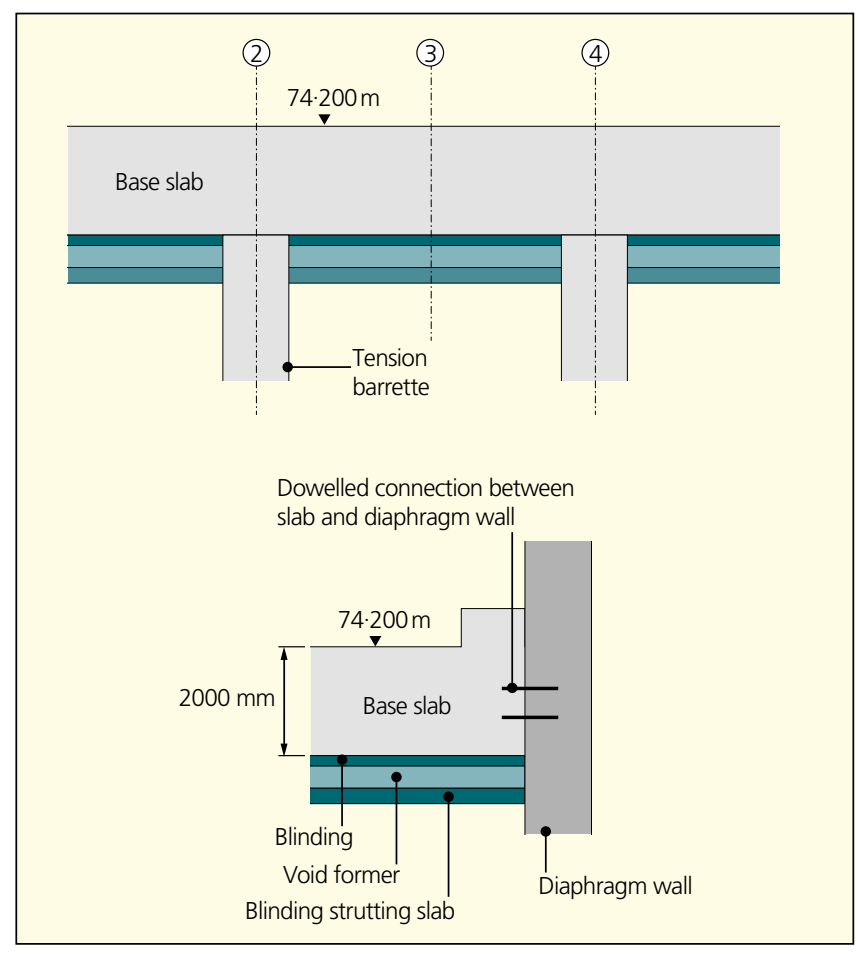

Figure 5. Detail of base slab 
This requires a minimum of $50 \mathrm{~mm}$ thickness of concrete in compression, or, where cracks may pass through the whole thickness of the section, crack widths limited to $0 \cdot 15 \mathrm{~mm}$ as the hydraulic gradient of 13.5 across the slab is greater than 5 . The joint with the diaphragm wall will be incorporated into the base of the lining walls where the watertight joint to the base slab is achieved with hydrophilic strips.

Very dense reinforcement was required to meet the crack width limitations. The reinforcement generally comprised three layers of B40 at $150 \mathrm{~mm}$ centres in each direction in the critical areas on top and bottom faces, and was curtailed to one layer of B40 reinforcement in the compression zones. However, the anchorage length of the reinforcement is so long that there were few areas without multiple layers of B40 reinforcement. Shear links were required across the whole area of the base, with a higher density around the perimeter and adjacent to the tension barrettes.

An earthing mat was required under the slab with watertight connections through to earth pits cast into the slab. A drainage network for fire water and seepage water was also cast into the slab. This drained to a sump on the east side of the slab.

The concrete was specified as a designed mix in accordance with BS 8500 (BSI, 2006b) suitable for exposure class XC3 and DC-4 due to aggressive ground conditions exacerbated by hydraulic gradient greater than 5 . Strength grade C35/45 was adopted for structural design, and a minimum cementitious content of $360 \mathrm{~kg} / \mathrm{m}^{3}$ and maximum water:cement ratio of 0.45 were specified.

The specification for concrete for the shaft works limited the peak concrete temperature to $70^{\circ} \mathrm{C}$ and the differential temperature between core and surface to $25^{\circ} \mathrm{C}$. The reinforcement design for early thermal effects assumed a concrete mix with $380 \mathrm{~kg} / \mathrm{m}^{3}$ cementitious content with $60 \%$ ground granulated blast-furnace slag. This mix was estimated to have an embodied carbon dioxide content of $70 \mathrm{~kg} / \mathrm{t} \mathrm{CO}$ e. Equivalent embodied carbon dioxide weights are calculated using the data in Specifying Sustainable Concrete (The Concrete Centre, 2011).

Temperatures were predicted using the spreadsheet associated with Ciria guide C660, Early age thermal crack control in concrete (Bamforth, 2007). For initial concrete and ambient temperature at $20^{\circ} \mathrm{C}$, the predicted differential temperature was $35^{\circ} \mathrm{C}$, and the predicted peak temperature was $65^{\circ} \mathrm{C}$. The $35^{\circ} \mathrm{C}$ differential temperature was not critical for the reinforcement design. The contractor was therefore permitted to relax the specified restriction on the differential temperature from $25^{\circ} \mathrm{C}$ to $35^{\circ} \mathrm{C}$ and made aware of potential difficulties in meeting the $70^{\circ} \mathrm{C}$ restriction on peak temperature in hot weather.

\section{Reinforcement detailing}

The reinforcement was detailed for the contractor by Capita. The reinforcement details were developed collaboratively with the contractor and the designer, reviewed by the designer and approved by the client. Due to the large bar diameter with relatively close spacing, use of lapped bars was difficult, and, due to the length of the laps, staggered laps not practicable. Full-strength parallel-threaded swaged couplers were therefore used to join all the main reinforcement. For standard couplers this was the lowest material cost.

Bridging couplers, which enable some adjustment in coupler length, were used generally to ensure that the running dimension of the cage could be maintained accurately. This coupled cage did not accommodate the variation in the position of the diaphragm walls which, taking account of construction tolerances, could be between $270 \mathrm{~mm}$ out of the shaft and $370 \mathrm{~mm}$ (including over-break) into the shaft.

A secondary cage, lapped onto the primary cage, was therefore detailed to ensure that reinforcement was present close to the diaphragm wall around the perimeter of the shaft to limit the length of the connecting dowels required (Figure 5). The actual as-built variation in diaphragm wall position was from $175 \mathrm{~mm}$ out of the shaft to $320 \mathrm{~mm}$ into the shaft after the face had been smoothed with a rock roller removing some of the over-break.

Shear-link reinforcement area requirements were met by using Linkstuds shear studs. These consist of a reinforcement bar with an upset forged end to provide an anchorage. They improved both safety and fixing productivity as they allowed the shear reinforcement to be lowered into the cage from above with no need for access inside the cage.

The six layers of the top mat were detailed to be fixed from the bottom up so that no reinforcement had to be threaded through the top mat. Three-dimensional (3D) computer modelling of the reinforcement was used to identify and resolve reinforcement clashes and gaps. Colour-coding of the reinforcement was used to clarify the layers; an example of this is shown in Figure 6. An example of the 3D model at the sump is shown in Figure 7, with the same area, as fixed, shown in Figure 8.

\section{Reinforcement fixing}

The top mat of reinforcement weighed a maximum of approximately $400 \mathrm{~kg} / \mathrm{m}^{2}$. This weight could not be supported on conventional reinforcement chairs. A support frame was designed by the contractor consisting of scaffold tube towers carrying ' $\mathrm{I}$ ' beams as shown in Figures 9 and 10. This was left in place with the scaffold tubes filled with grout to prevent voids and limit seepage paths through the structure.

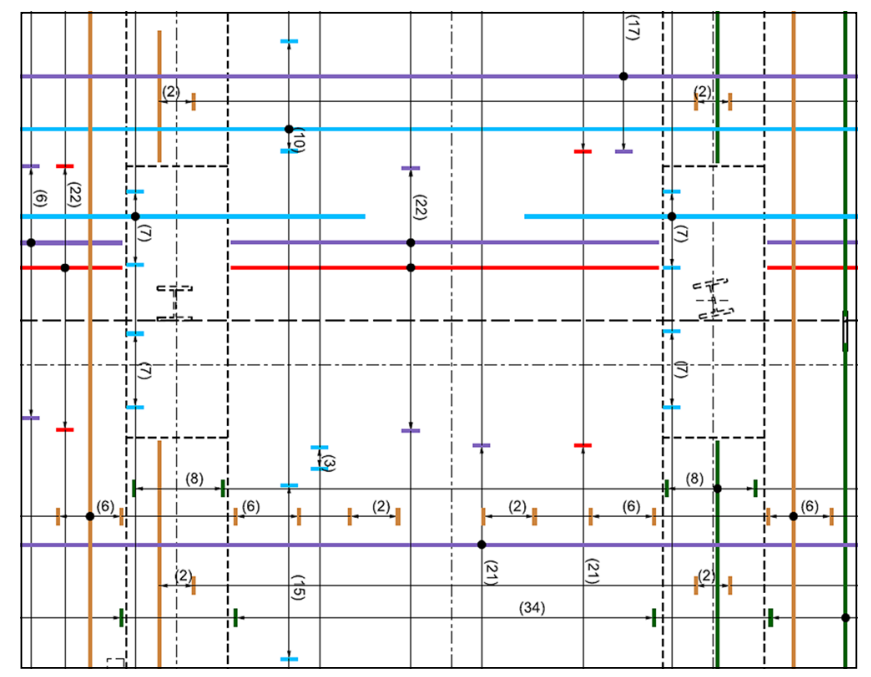

Figure 6. Colour-coded reinforcement detail drawing 
Delivering the Moorgate shaft base slab on Crossrail, UK

Douglas, Smith and Hunter

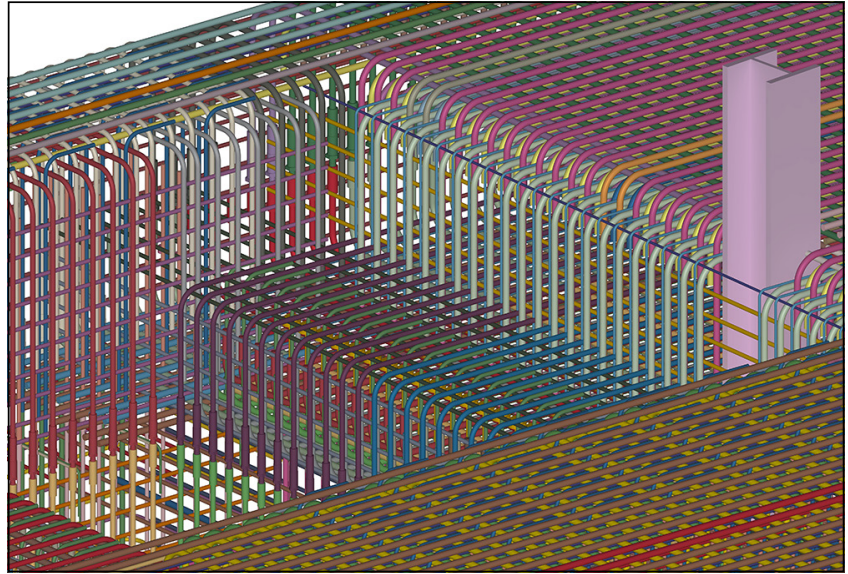

Figure 7. Three-dimensional model of reinforcement cage at sump

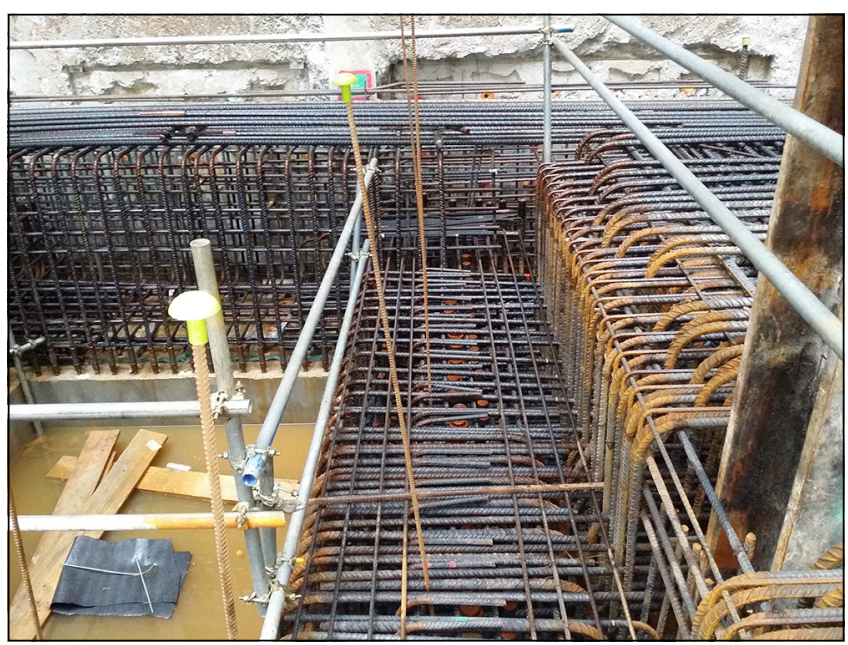

Figure 8. Reinforcement cage at sump

The local pressure under the base plates with this arrangement exceeded the collapse load of the specified void former. A stronger void former was developed by Cordek to support the loads during execution determined in accordance with BS EN 1991-1-6 (BSI, 2005), including loads from reinforcement supports, heaped wet concrete and construction activities. It was demonstrated through testing that the maximum load after collapse at the required deformation of $140 \mathrm{~mm}$ was within the original design assumptions. The test result is shown in Figure 11.

The barrette starters were fixed after the bottom mat. Straight starters were coupled onto the barrette reinforcement with anchorage terminators at the top. The reinforcement grid had to be accurately placed to ensure that the coupled starter bars for the internal walls could be placed within the required tolerance. Several temporary man-access openings were left in the top mat to allow safe access and egress for the fixing of drainage and earthing connections to be carried out within the reinforcement cage, as shown in Figure 12. These openings were closed before the start of concreting.

The difficulties and safety concerns of working inside the cage are illustrated by Figure 13, showing the drainage, and by

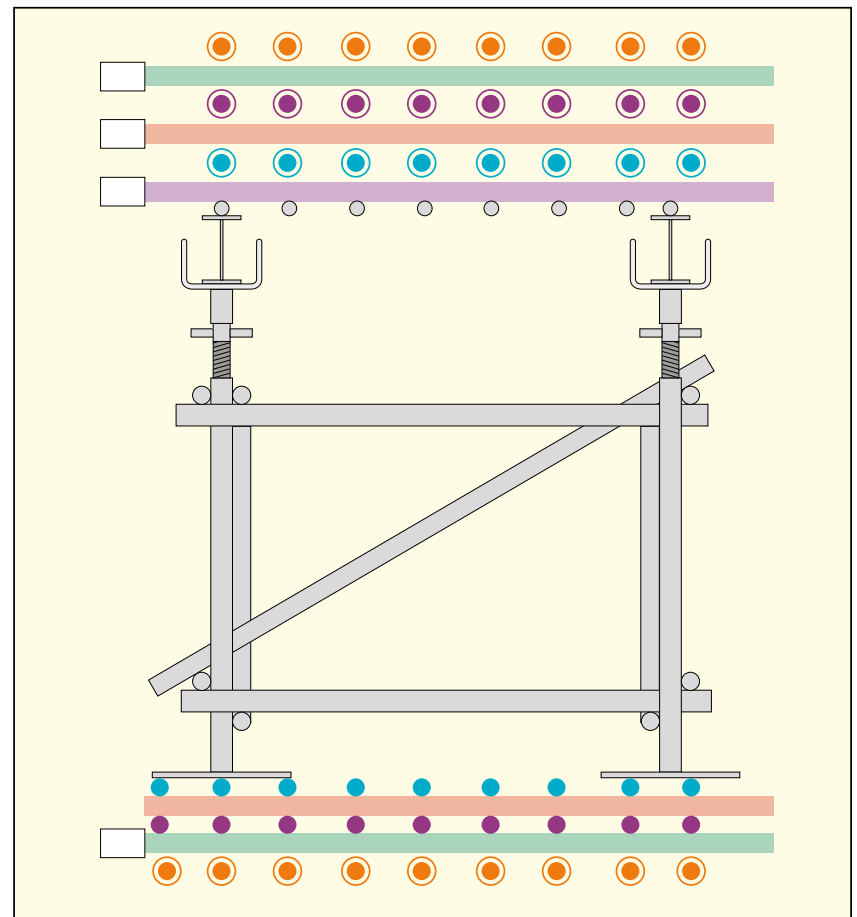

Figure 9. Reinforcement support frame

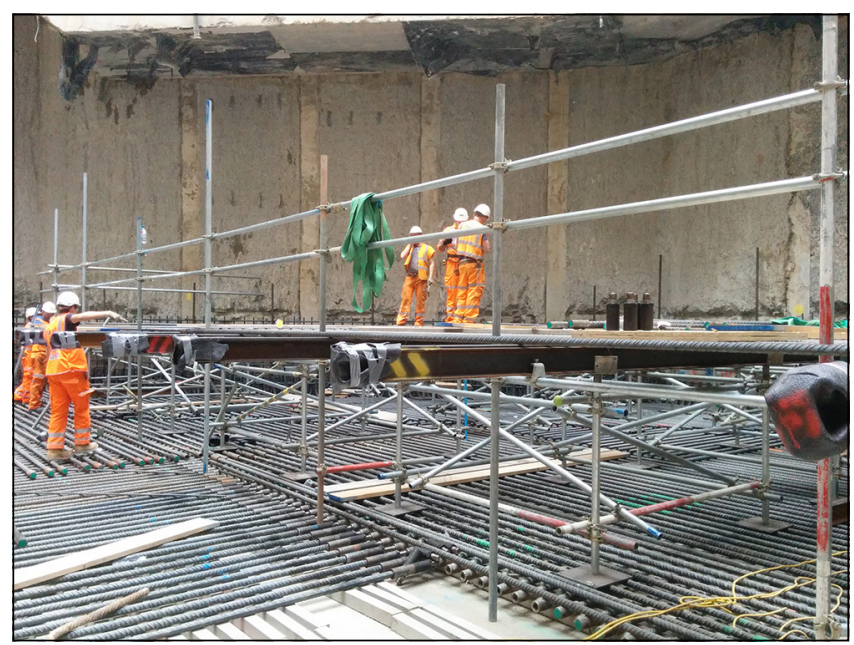

Figure 10. Support frames for top reinforcement

Figure 14, which shows the cage after the shear studs were placed. These concerns were mitigated through collaborative reviews between the design and construction teams.

Quality control was through self-certification by the contractor with review by the client. During steel fixing, an innovative approach was adopted for the reinforcement snagging with the snags being identified with a label tied to the cage by the engineers describing the issue. These were then snipped by the steel fixers when resolved before being removed by the engineer. Describing the location of the snag had proved ineffectual on the large uniform base slab. 
Civil Engineering

Volume 168 Issue CE4
Delivering the Moorgate shaft base slab on Crossrail, UK Douglas, Smith and Hunter

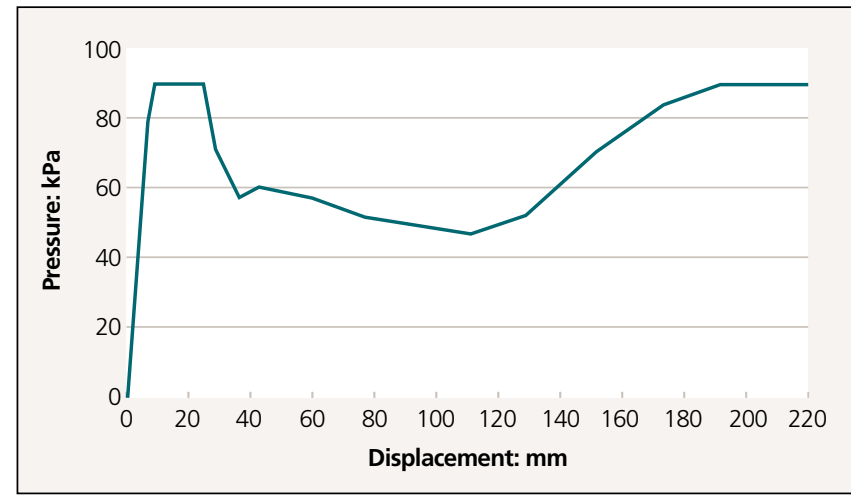

Figure 11. Load-deflection curve of void former

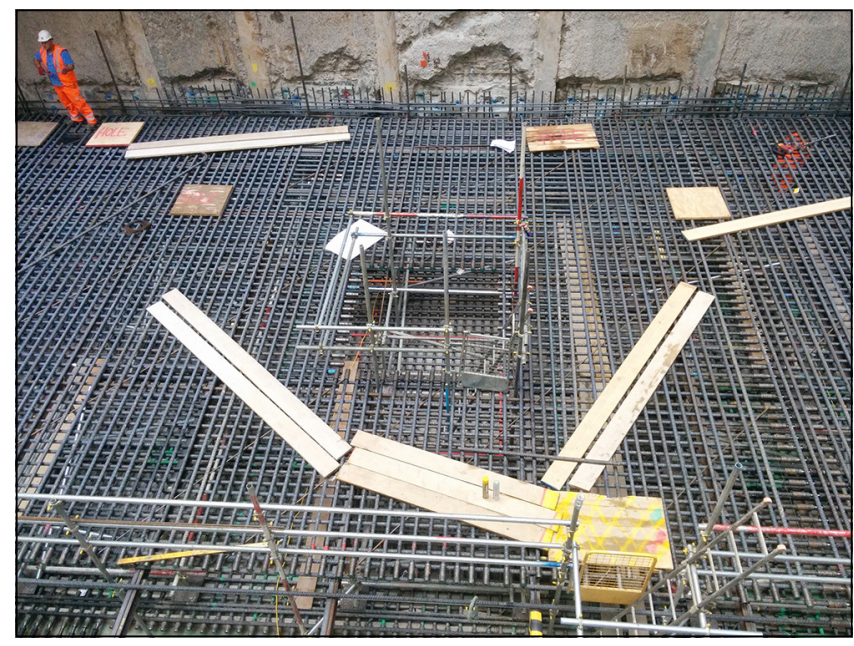

Figure 12. Access opening in top mat

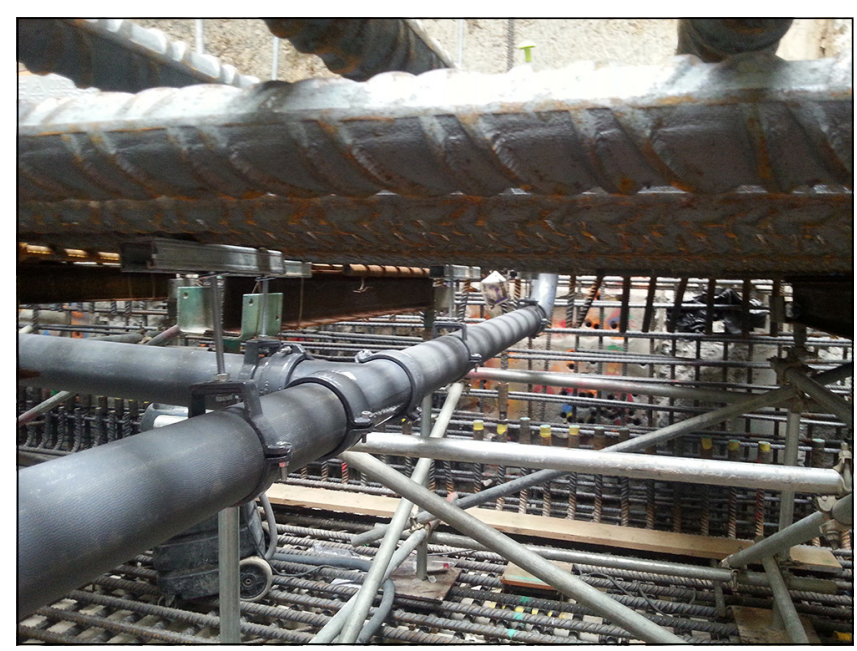

Figure 13. Drainage pipes within reinforcement cage

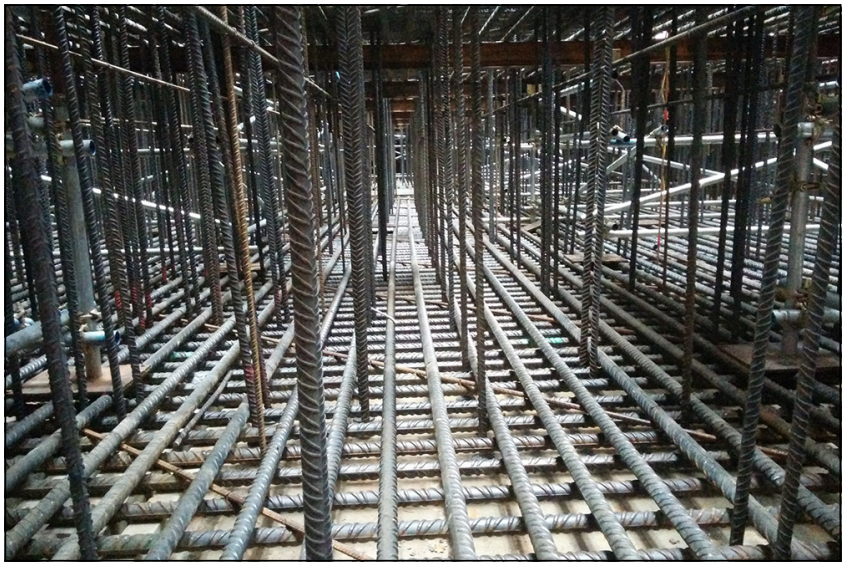

Figure 14. Shear studs inside reinforcement cage

\section{Concrete mix design development}

The contractor required a concrete mix with an F5 consistency to enable placing by pump in the heavy, dense and, in places, congested reinforcement. In order to achieve this and comply with the specification Hanson offered a preliminary mix with $425 \mathrm{~kg} / \mathrm{m}^{3}$ of cementitious material with $70 \%$ ground granulated blast-furnace slag. The estimated embodied carbon dioxide for this mix was of $60 \mathrm{~kg} / \mathrm{t} \mathrm{CO}$ e. The high cement content of this mix raised concerns with temperature development during curing. In discussions between the designer and Hanson, facilitated by the client, designer and contractor site teams, it was agreed to modify the specification to allow a more practical concrete mix based on results of tests on the trial mix and accepting concrete strength tested at 56 days.

The revised mix was tested for temperature development and for initial set. The revised mix is presented in Table 2 .

\begin{tabular}{|c|c|c|}
\hline Material & Quantity: kg/m³ & Description \\
\hline Cement & 117 & CEM1 $(30 \%)$ \\
\hline Cement replacement & 273 & $\begin{array}{l}\text { Ground granulated blast- } \\
\text { furnace slag }(70 \%)\end{array}$ \\
\hline Total cementitious material & & $390 \mathrm{~kg} / \mathrm{m}^{3}$ \\
\hline Aggregate $10-20 \mathrm{~mm}$ & 445 & Limestone \\
\hline Aggregate $4-10 \mathrm{~mm}$ & 445 & Limestone \\
\hline Aggregate $0-4 \mathrm{~mm}$ & 890 & Marine sand \\
\hline Filler & 40 & Limestone powder \\
\hline Water & 170 & \\
\hline Total & 2380 & \\
\hline Water cement ratio & & 0.44 \\
\hline $\begin{array}{l}\text { Embodied equivalent } \\
\text { carbon dioxide }\end{array}$ & & $55 \mathrm{~kg} / \mathrm{t} \mathrm{CO} \mathrm{C}_{2}$ \\
\hline Admixtures & Dose: $1 / \mathrm{m}^{3}$ & \\
\hline Superplasticiser & $2 \cdot 37$ & Sika ViscoFlow 1000 \\
\hline Retarder & 0.43 & SikaTard R \\
\hline Shrinkage control & $4 \cdot 30$ & Sika Control 40 \\
\hline
\end{tabular}

Table 2. Concrete mix design 
It has $390 \mathrm{~kg} / \mathrm{m}^{3}$ of cementitious material with $70 \%$ ground granulated blast-furnace slag. The estimated embodied carbon dioxide for this mix was of $55 \mathrm{~kg} / \mathrm{t} \mathrm{CO}_{2} \mathrm{e}$. Superplasticiser, retarder and shrinkage-reducing admixtures were used. An initial set delayed to $13 \mathrm{~h}$ after batching was demonstrated through penetration testing. The results of the penetration testing are shown in Figure 15. The pour was programmed to spread the concrete in $500 \mathrm{~mm}$ deep layers working from east to west so that there was no more than $6 \mathrm{~h}$ before each layer was covered with the subsequent layer.

The temperature test was carried out with a $2 \mathrm{~m}$ test cube cast onto the void former material to simulate the insulation this provides at the bottom of the pour. The input parameters for the spreadsheet provided with Ciria guide C660 on early thermal shrinkage were adjusted to match the temperatures measured in the test cube. The thickness was increased to represent the insulation on the underside of the pour and the thermal capacity of the concrete adjusted to match the rate of temperature change. The time from batching was adjusted to match the time of peak temperature to account for the effect of the retarder. The results of the test and the calibrated Ciria guide C660 spreadsheet predictions are shown in Figure 16.

A good fit for maximum temperature was achieved, except for the surface temperature which was sensitive to the ambient temperature after the pour. The differential temperature was underestimated.

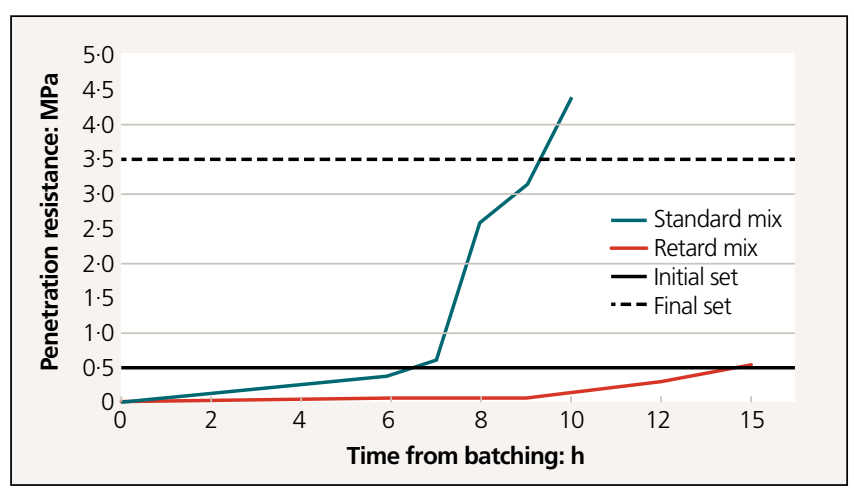

Figure 15. Penetration testing for initial set of retarded mix

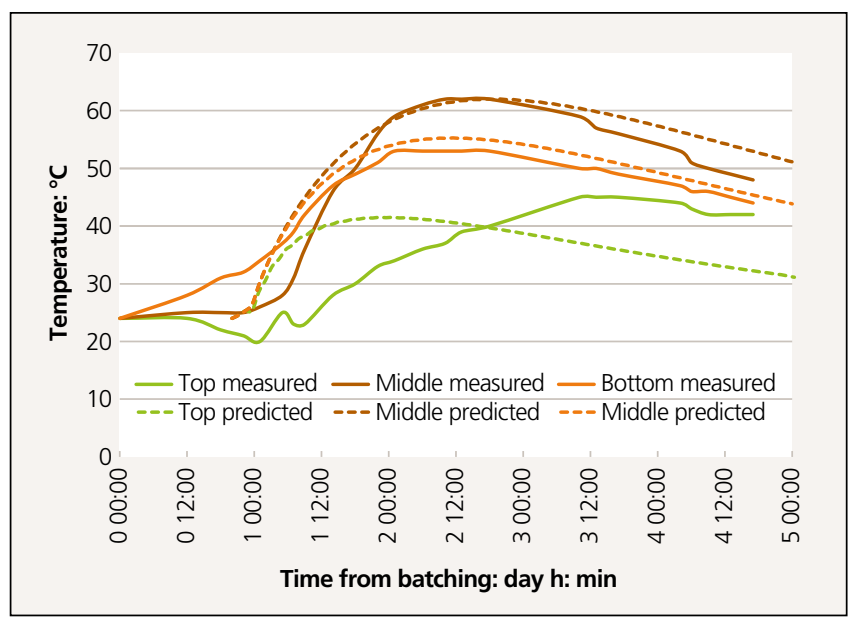

Figure 16. Temperatures measured and predicted for trial cube
With this mix there was still a risk of excessive peak temperatures if the ambient temperature and delivered concrete temperature were high. Maximum differential temperatures were predicted assuming delivery temperature of $15^{\circ} \mathrm{C}$ and ambient temperature of $5^{\circ} \mathrm{C}$.

The peak and differential temperatures can be controlled on site by a combination of blowing hot or cold air in to the base of the shaft and placing or removing insulating frost blankets. Based on the results of the testing, trigger values were developed for ambient temperature at which mitigation measures would be deployed or removed. The maximum ambient temperature trigger of $25^{\circ} \mathrm{C}$ was set to give a predicted peak temperature of $65^{\circ} \mathrm{C}$, above which cooling measures would be required.

Thermocouples were installed in the slab to monitor concrete temperature so that mitigation measures could be implemented if required. Nine sets of three thermocouples were distributed across the slab. Each set consisted of a thermocouple near the top surface, in the centre of the slab and near the bottom. Temperature monitoring was required for 7 days after the pour, but in the event this was extended to 13 days as it was not disrupting any subsequent activities.

The temperature at the bottom of the shaft differed from the temperature at street level. In the run up to the base pour, records were kept over several weeks of the variation in temperature between the top and bottom of the shaft. The recorded temperatures and the upper and lower bound estimates are shown in Figure 17.

Trigger values for mitigation measures for controlling concrete temperature were set for predicted temperatures at the bottom of the shaft. These were to be adjusted from the forecast temperature for the estimated differences at the bottom of the shaft. This was particularly relevant for cold forecast temperatures where the bottom of the shaft was found to be approximately $2^{\circ} \mathrm{C}$ warmer than the surface.

\section{Pour preparation}

The client site team, the designer and the contractor were aware that this was a critical concreting operation with severe consequences to the project if the pour had to be aborted or if cold joints were

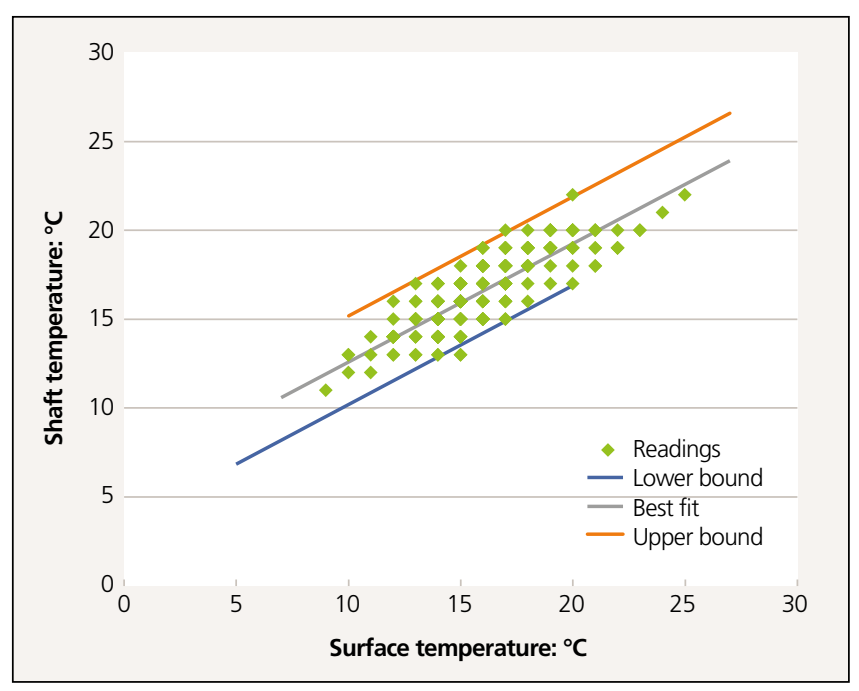

Figure 17. Relation between shaft temperature and surface temperature 
formed, with no opportunity for remedial action during the pour and limited remedial options after the pour. The designer therefore advised the client to request a detailed pour plan from the contractor to include contingency measures to address foreseeable difficulties during the pour. The requirements for the pour plan were developed from the concrete execution standard BS EN 13670 (BSI, 2009).

The main concerns were interruption of the concrete supply and control of temperatures in the concrete during initial curing. The risks and contingency measures in place are summarised in Table 3 .

Three batching plants were planned to be used during the pour with the supply split as follows: $1100 \mathrm{~m}^{3}$ from Kings Cross, $600 \mathrm{~m}^{3}$ from Silvertown and $300 \mathrm{~m}^{3}$ from Victoria Deep in Greenwich. A second batching plant at Victoria Deep was designated as a back-up. This arrangement provided redundancy in the supply; while two plants could provide the required supply rate, the third plant covered for shift changes and minor delays at any of the other plants. Should any batching plant fail then the other two would increase their production to cover the shortfall. The back-up plant was stocked and approved but would only be required if one of the other plants stopped production.

Transport from the batching plants was planned to use 14 wagons from Kings Cross with a journey time of $12 \mathrm{~min}$, nine wagons from Silvertown with a journey time of $14 \mathrm{~min}$ and two wagons from Victoria Deep with a journey time of 18 min Designated primary and secondary routes were identified using client-approved lorry routes. Maps of the routes were provided to the drivers. Separate marshalling areas were defined for each concrete pump. The routes local to the site are shown in Figure 18.

Table 4 lists the resources planned for the pour. The pour was scheduled for early November. The planned pour rate was for a

\begin{tabular}{|c|c|c|c|}
\hline Risk & Consequence & Potential cause & Contingency measures identified \\
\hline \multirow{6}{*}{$\begin{array}{l}\text { Interrupted } \\
\text { concrete } \\
\text { supply }\end{array}$} & \multirow{2}{*}{$\begin{array}{l}\text { Joint required in } \\
\text { base slab }\end{array}$} & \multirow[t]{2}{*}{ Failure of batching plant } & Use of multiple batching plants \\
\hline & & & Fitters to be on stand-by for each batching plant \\
\hline & $\begin{array}{l}\text { Base slab is not } \\
\text { assured to be } \\
\text { watertight }\end{array}$ & $\begin{array}{l}\text { Material shortage at batching } \\
\text { plant }\end{array}$ & $\begin{array}{l}\text { Sufficient stock piles at the batching plants and plan in place to resupply batching plant } \\
\text { or use alternative plant }\end{array}$ \\
\hline & \multirow[t]{3}{*}{$\begin{array}{l}\text { Breakout and } \\
\text { re-work }\end{array}$} & Disruption to transport & $\begin{array}{l}\text { Alternative traffic routes identified from each batching plant } \\
\text { Additional vehicles available to provide redundancy }\end{array}$ \\
\hline & & $\begin{array}{l}\text { Poor communication between } \\
\text { site and batching plants }\end{array}$ & $\begin{array}{l}\text { Single point of contact between site and concrete supplier established with backup } \\
\text { contacts }\end{array}$ \\
\hline & & & $\begin{array}{l}\text { In the event of the pour being abandoned part way through expanded metal stop ends } \\
\text { installed within reinforcement cage to form a construction joint }\end{array}$ \\
\hline $\begin{array}{l}\text { Concrete peak } \\
\text { temperature } \\
\text { exceeded }\end{array}$ & $\begin{array}{l}\text { Change in concrete } \\
\text { chemistry with } \\
\text { delayed ettringite } \\
\text { formation }\end{array}$ & $\begin{array}{l}\text { High concrete temperature } \\
\text { when poured }\end{array}$ & $\begin{array}{l}\text { Thermocouples installed in pour to be monitored for } 10 \text { days after completion } \\
\text { Forced ventilation of shaft } \\
\text { Maximum concrete placing temperature }\left(25^{\circ} \mathrm{C}\right)\end{array}$ \\
\hline \multirow[t]{2}{*}{$\begin{array}{l}\text { Concrete } \\
\text { differential } \\
\text { temperature }\end{array}$} & \multirow[t]{2}{*}{$\begin{array}{l}\text { Excessive cracking of } \\
\text { concrete } \\
\text { Reduced } \\
\text { watertightness, } \\
\text { reduced durability }\end{array}$} & $\begin{array}{l}\text { Cold surface temperature } \\
\text { during curing }\end{array}$ & $\begin{array}{l}\text { Insulate top surface } \\
\text { Blow warm air into shaft } \\
\text { Trigger value for ambient temperature }\left(2^{\circ} \mathrm{C}\right) \text { (equivalent to } 5^{\circ} \mathrm{C} \text { at the bottom of the } \\
\text { shaft) }\end{array}$ \\
\hline & & High core temperature & Trigger value for differential temperature $\left(30^{\circ} \mathrm{C}\right)$ \\
\hline \multirow{5}{*}{$\begin{array}{l}\text { Adverse } \\
\text { weather } \\
\text { conditions }\end{array}$} & \multirow[t]{5}{*}{ Damage to concrete } & General & Monitoring weather forecast for duration of pour \\
\hline & & Solar heating & $\begin{array}{l}\text { Trigger level for concrete temperatures set } \\
\text { Relation between surface and shaft temperature established }\end{array}$ \\
\hline & & Wind & $\begin{array}{l}\text { Not relevant at bottom of shaft } \\
\text { Limitations for cranes and concrete pumps established }\end{array}$ \\
\hline & & Freezing & $\begin{array}{l}\text { Trigger levels for concrete temperatures set } \\
\text { Relation between surface and shaft temperature established }\end{array}$ \\
\hline & & Snow & Postpone pour if snow is forecast before concrete is predicted to have achieved final set \\
\hline \multirow[t]{2}{*}{$\begin{array}{l}\text { Preparation } \\
\text { work } \\
\text { incomplete }\end{array}$} & \multirow[t]{2}{*}{$\begin{array}{l}\text { Delayed start to } \\
\text { pour }\end{array}$} & $\begin{array}{l}\text { Reinforcement not fixed correctly } \\
\text { Pour area not clean } \\
\text { Insufficient cover } \\
\text { Traffic management closures } \\
\quad \text { not in place }\end{array}$ & Quality control procedures for pour identified in pour plan and inspection and test plan \\
\hline & & $\begin{array}{l}\text { Construction equipment not } \\
\text { available }\end{array}$ & Full labour and plant lists included in the pour plan \\
\hline
\end{tabular}

Table 3. Risks and contingencies for pour 


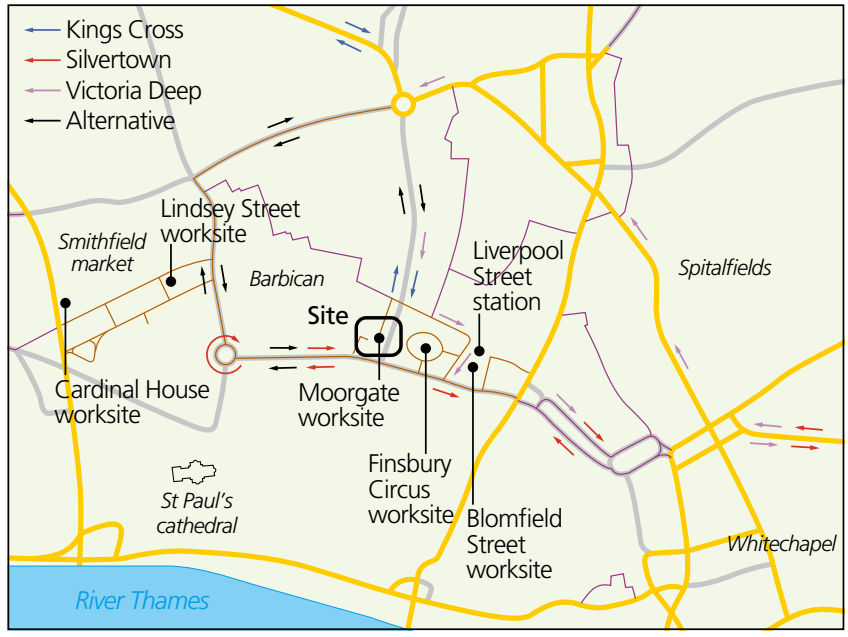

Figure 18. Routes into the holding areas

maximum of $120 \mathrm{~m}^{3} / \mathrm{h}$. The complete pour of $1750 \mathrm{~m}^{3}$ was scheduled to take $18-30 \mathrm{~h}$ to allow for any delays. The road closure for the pour was booked from 20:00 on Friday through to 06:00 on Monday to allow for setting up, clearing away and significant delays.

Within the shaft an access bridge was constructed from the main access jetty over to the previously cast sump to enable exit from the shaft bottom after finishing to one side of the slab (Figure 24). The site canteen was planned to be open throughout the pour and free of charge. In the days leading up to the pour the following were put into place.

- All quality control documentation for construction drawings, material conformance records and so on, agreed and signed off.

- Testing of dowel bars and embedded drainage completed.

\begin{tabular}{|c|c|c|}
\hline Personnel (each shift) & Equipment & Materials \\
\hline $\begin{array}{l}\text { The contractor } \\
\text { nominated concrete } \\
\text { co-ordinator } \\
\text { Three shift engineers } \\
\text { One electrician } \\
\text { Two slingers } \\
15 \text { concrete operatives } \\
\text { One concrete wagon } \\
\text { booking operative } \\
\text { Six operatives at the } \\
\text { concrete pump } \\
\text { Six security guards } \\
\text { Canteen staff } \\
\text { Five gate men } \\
\text { Six concrete-testing } \\
\text { technicians } \\
\text { Traffic management } \\
\text { sub-contractor team } \\
\text { Three main concrete } \\
\text { pump drivers } \\
\text { One back-up pump } \\
\text { driver }\end{array}$ & $\begin{array}{l}\text { Two no. } 63 \text { m reach } \\
\text { concrete pumps } \\
\text { One no. } 36 \text { m reach } \\
\text { concrete pump } \\
\text { One no. } 56 \text { m reach } \\
\text { concrete pump } \\
\text { (back-up) } \\
\text { Tower crane } \\
\text { Crawler crane } \\
\text { Vibrating pokers } \\
\text { Hand tools } \\
2 \text { m }^{3} \text { concrete skip } \\
3 \mathrm{~m}^{3} \text { concrete skip } \\
\text { Roller screeds } \\
\text { Three batching plants } \\
25 \text { concrete wagons } \\
\text { Thermocouples and } \\
\text { data loggers } \\
\text { Three propane heaters }\end{array}$ & $\begin{array}{l}\text { Frost blanket } \\
\text { Screed rails } \\
\text { Stainless steel tying wire } \\
\text { Spray-applied curing } \\
\quad \text { membrane } \\
\text { Full diesel bowser }\end{array}$ \\
\hline
\end{tabular}

Table 4. Resources planned for pour
- Record sheets prepared and sufficient printed off.

- Concrete placement lines assembled on reinforcement.

- Screed rails set to level and secured.

- Thermocouples installed.

- Embedded drainage pipes filled with water to prevent flotation.

- Proposed traffic routes inspected for diversions or road works.

\section{Concrete pour}

The road closure for the pour was put into place at 20:00 on Friday. The two $63 \mathrm{~m}$ reach Camfaud concrete pumps were set up on Moorgate to the east of the shaft, aligned so that one received concrete wagons from the north and the other from the south. The $36 \mathrm{~m}$ reach pump was set up to the north of the shaft and connected to a static line installed for the shaft construction as shown in Figure 4.

The first concrete was delivered at 23:10. It was found that the reach of the $63 \mathrm{~m}$ reach pumps was sufficient to cover the whole area of the pour so the moveable concrete lines on the reinforcement cage were deemed unnecessary and removed. When planning the pump layout it was assumed that the arms were vertical or horizontal. In practice it was possible to angle some of the arm segments down the shaft with some increase in reach. The $36 \mathrm{~m}$ reach pump was stood down from 10:30 on Saturday. Only one of the $63 \mathrm{~m}$ reach pumps was used from 15:00 on the Saturday, the reduced pour rate allowing for the effort required for finishing. Concreting was complete by 16:15. The number of wagons departing each hour is shown in Figure 19.

There were no delays to the concrete supply or incidents during the pour. Review of the delivery tickets indicated that a maximum pour rate of $150 \mathrm{~m}^{3}$ was sustained for $1 \mathrm{~h}$. The pour rate was reduced to $100 \mathrm{~m}^{3}$ per hour during the shift change around 06:00 on Saturday morning. The entire $1750 \mathrm{~m}^{3}$ had been placed in just over $17 \mathrm{~h}$.

The delivery temperature of the concrete (shown in Figure 20) varied from $14^{\circ} \mathrm{C}$ to $18^{\circ} \mathrm{C}$ with an average of $15 \cdot 8^{\circ} \mathrm{C}$ with no clear correlation to ambient temperature. The flow had a limiting range of $530 \mathrm{~mm}$ to $660 \mathrm{~mm}$. Measured flow, shown in Figure 21, had an average of $618 \mathrm{~mm}$. Only two of the 50 test results were greater than the upper limit of $660 \mathrm{~mm}$.

The only causes for concern were the unseasonably high temperature of $21^{\circ} \mathrm{C}$ on the Saturday afternoon and the heavy rain on the Sunday afternoon. Inspection of the concrete surface, when accessible on the Monday showed that the rain had not had any detrimental effects.

The equipment and progress of the pour are illustrated in Figures 22-26.

\section{Temperature in slab}

Temperatures were monitored after the concrete pour. The concrete temperature when poured varied between $15^{\circ} \mathrm{C}$ and $23^{\circ} \mathrm{C}$. As the predicted maximum temperature was based on a maximum delivery temperature of $25^{\circ} \mathrm{C}$, with the low ambient temperatures in the first week there was no cause for any contingency measures. The predicted temperature shown in Figure 27 is based on the average as-placed concrete temperature of $15 \cdot 8^{\circ} \mathrm{C}$. 
Delivering the Moorgate shaft base slab on Crossrail, UK Douglas, Smith and Hunter

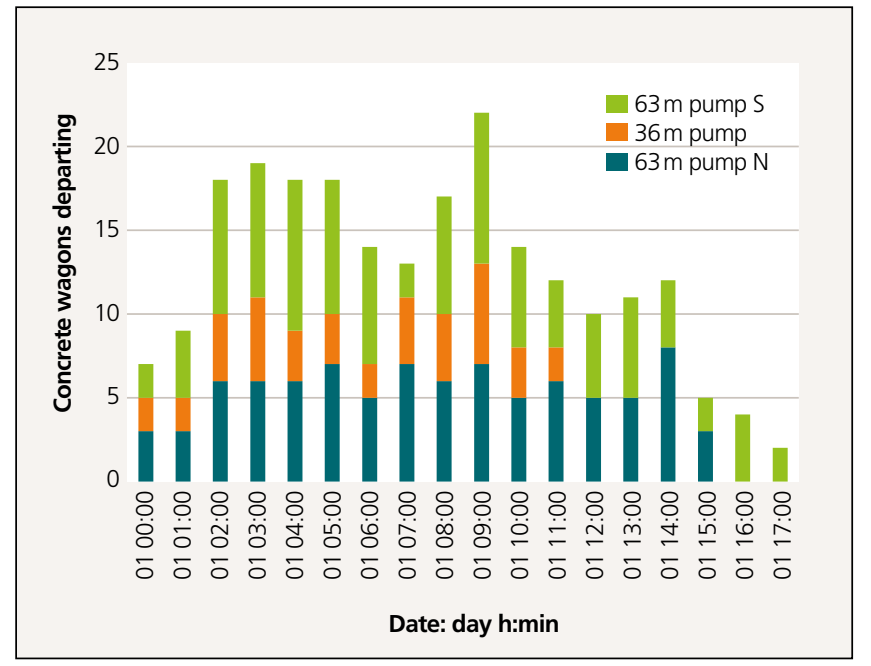

Figure 19. Number of concrete wagons departing each hour during the pour

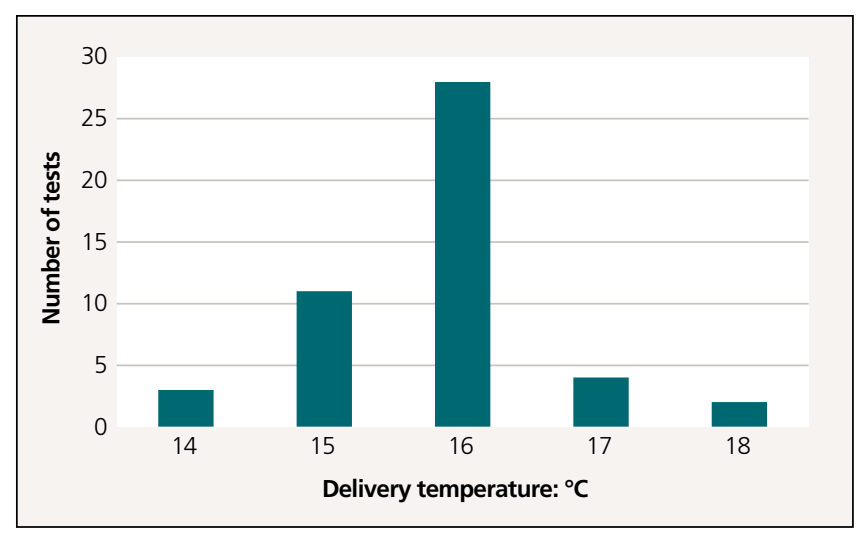

Figure 20. Variation of concrete delivery temperature

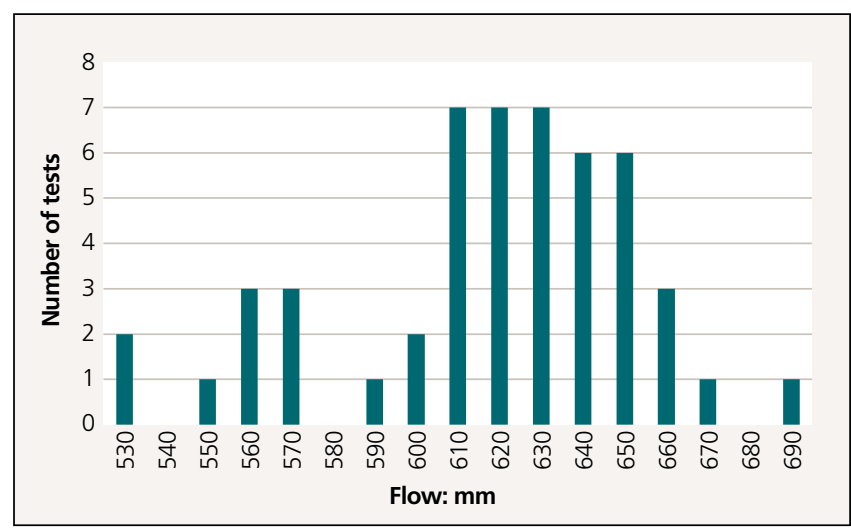

Figure 21. Variation of measured concrete flow at delivery

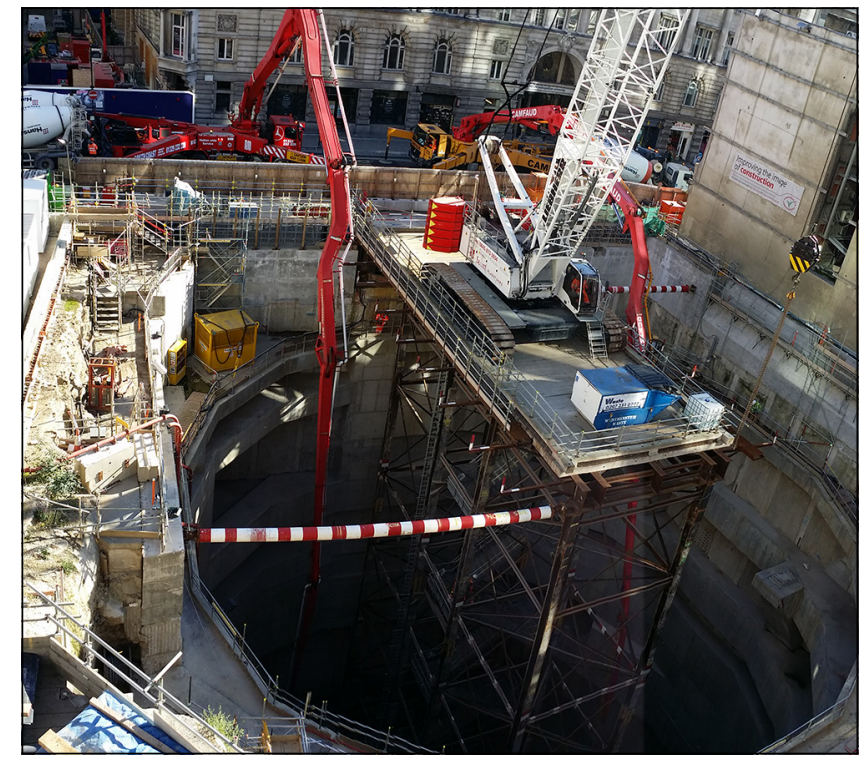

Figure 22. The two $63 \mathrm{~m}$ reach pumps on Moorgate

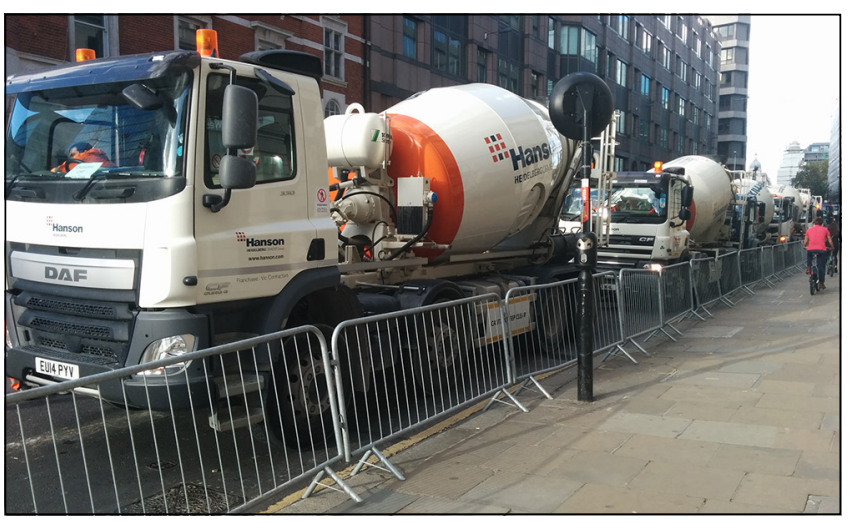

Figure 23. Wagons marshalled on Moorgate

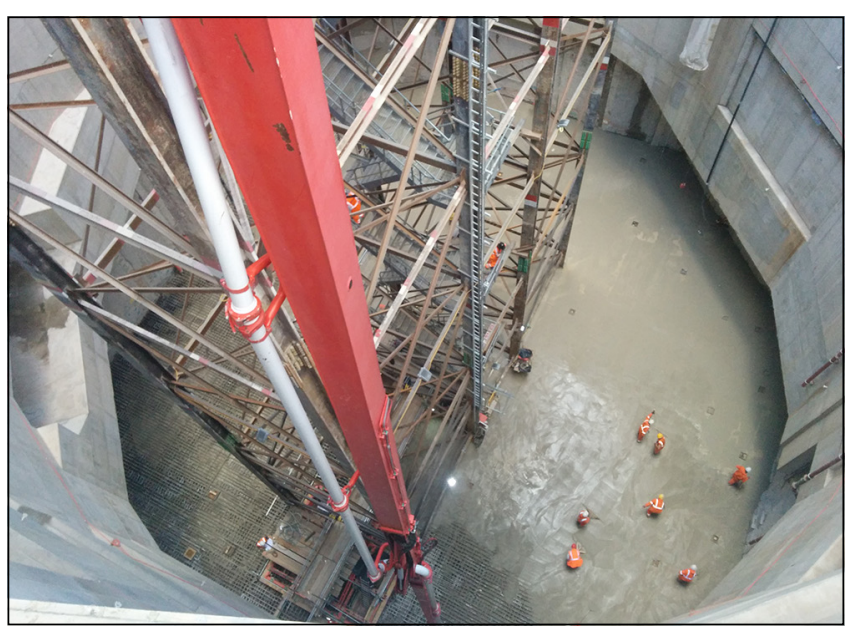

Figure 24. Nearing completion 


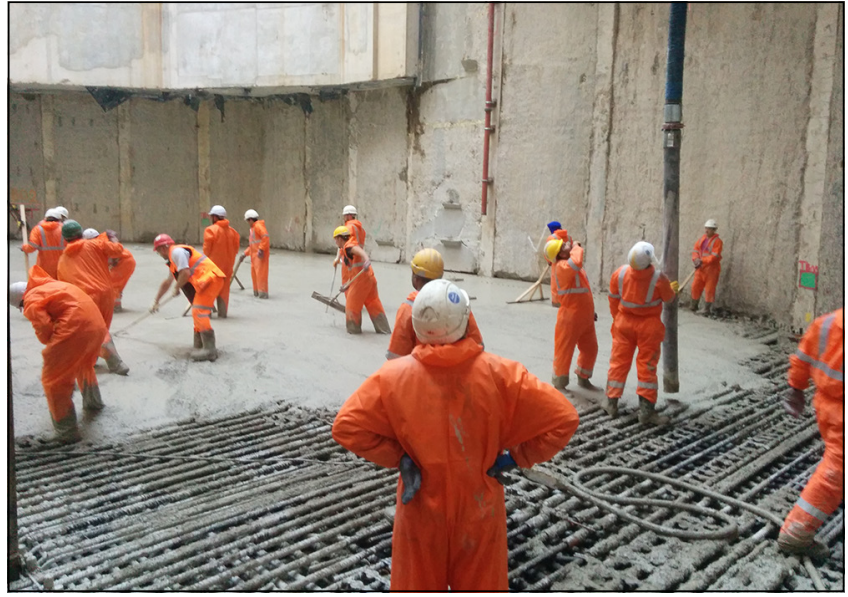

Figure 25. Finishing works

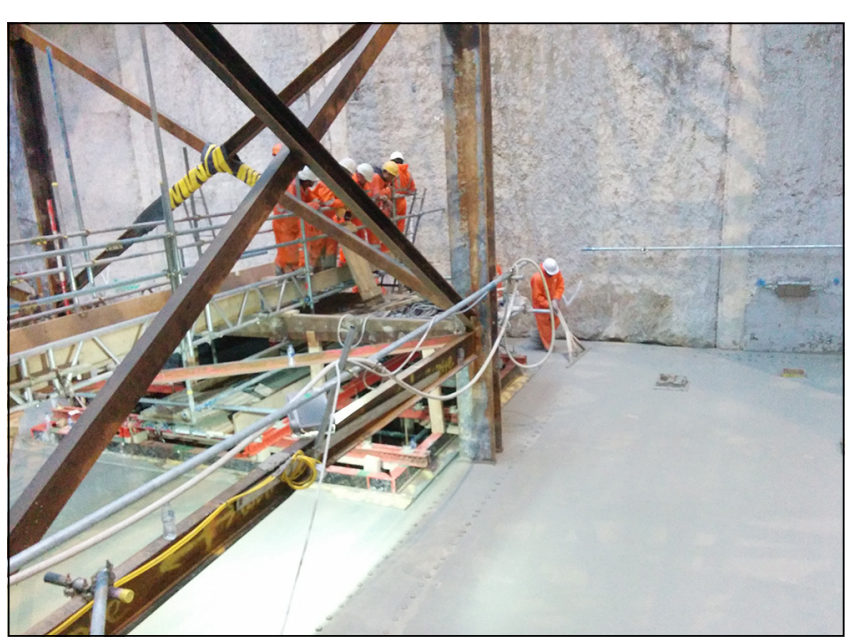

Figure 26. Last man off

The initial fall in temperature is estimated accurately, but after about 5 days there is a significant divergence between measured and predicted temperature. The differential temperature, shown in Figure 28, was underestimated, but the time of the maximum differential temperature was accurately predicted.

The development over time of the temperature profile through the slab is shown in Figure 29. Initially, the measured and predicted profiles are similar, but after 4 days they have diverged with the bottom temperature remaining much higher than predicted. At 10 days, although the surface temperature is similar to the predicted value, the peak and bottom temperatures are significantly higher than predicted.

\section{Cube tests}

Cubes were taken for concrete strength compliance from each $100 \mathrm{~m}^{3}$ of concrete delivered. These were tested at 7 days and 28 days under standard test conditions as the trial mix had indicated that testing at 56 days was not required.

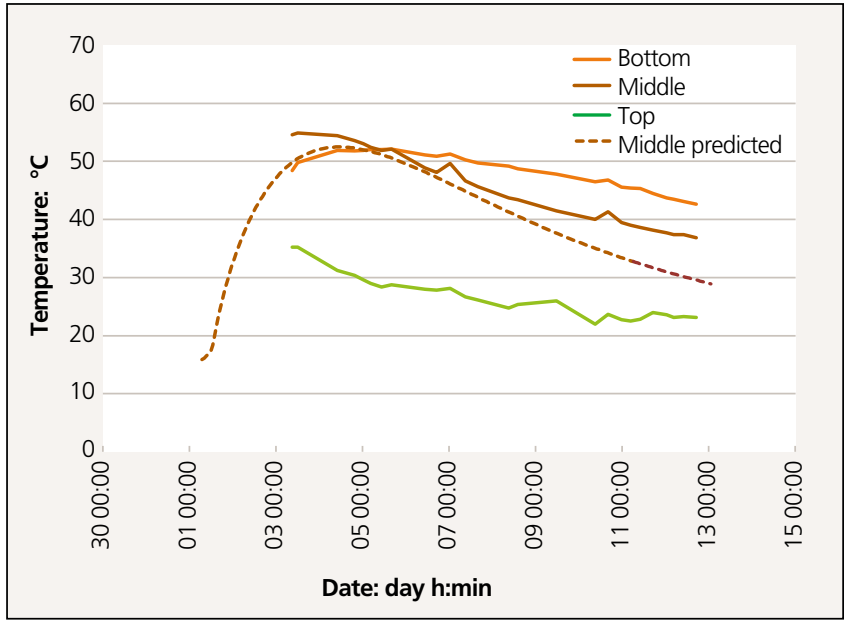

Figure 27. Actual and predicted temperature in slab

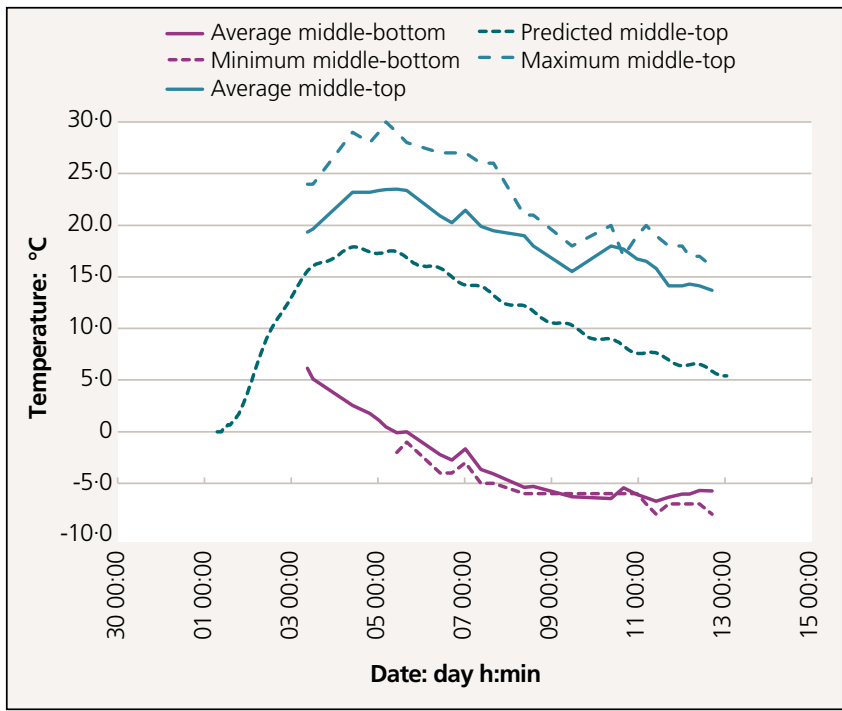

Figure 28. Actual and predicted differential temperature in slab

The follow-on works in the shaft could not start until the slab concrete had reached the $30 \mathrm{MPa}$ design strength. This was expected to be achieved with the 7 day cubes. The test results for the 7 day cubes are shown in Figure 30.

The average of the first six cubes was less than required. However, two of the lowest-strength cubes were sampled late on Friday and therefore tested at slightly less than 7 days. These were in the bottom layer of the pour and remote from where the follow-on contractor wished to start work. In practice, the follow-on works did not start until late on Saturday and the work did not significantly load the slab until early the following week so there were no concerns over the strength. The results were slightly lower than the trial mix which is possibly due to adjustments in the dose of retarder.

The 28 day cube test results are summarised in Figure 31. These show that the design strength of $45 \mathrm{MPa}$ is exceeded. Due to a single low test result the characteristic strength of the results is 


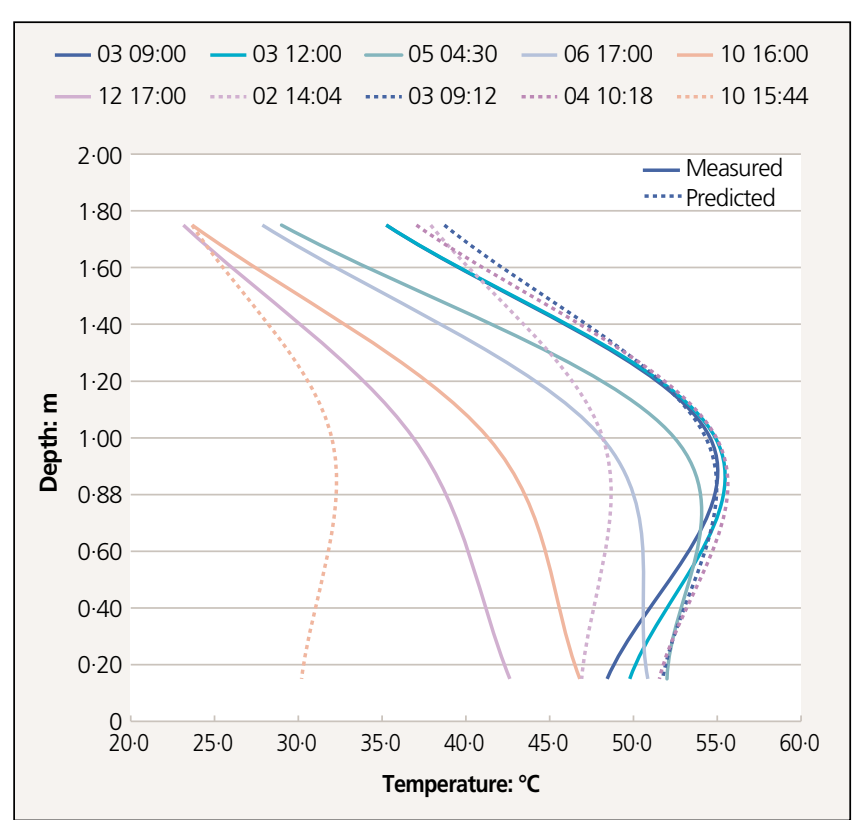

Figure 29. Actual and predicted temperature profile in slab

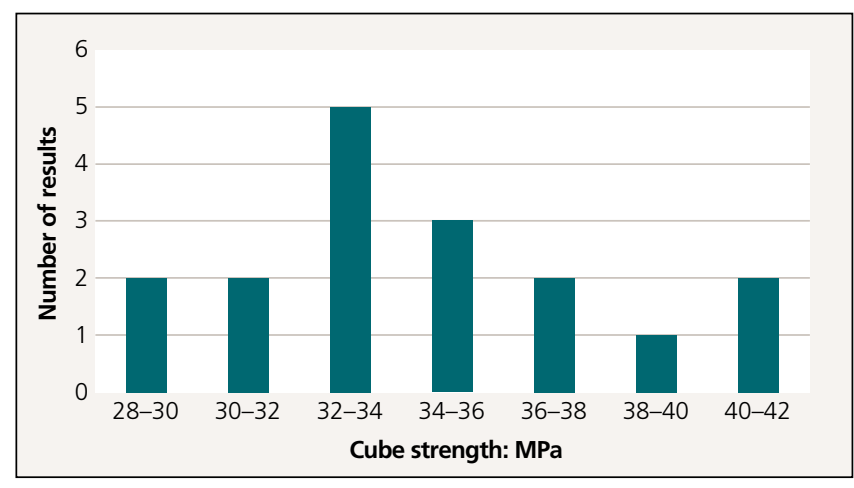

Figure 30. Concrete cube strength tests at 7 days

$53 \mathrm{MPa}$, that is $4 \mathrm{MPa}$ more than the lowest result, in accordance with BS EN 206 (BSI, 2013).

\section{Conclusions}

The temperature monitoring of the slab gave the project team confidence that a watertight concrete slab had been achieved within the specified parameters. Temperature prediction gave mixed results. When significant heat is being generated by the setting concrete the Ciria guide C660 spreadsheet matches the measured temperature accurately, but during the cooling phase this is not the case, and is attributed to the slab being cast onto a well-insulated base. The peak concrete temperature is accurately predicted and the maximum differential temperature reasonably predicted.

Separating design intent for the reinforcement from the detailing by the contractor, although normal practice for buildings, was difficult to manage for this heavy civil engineering work.

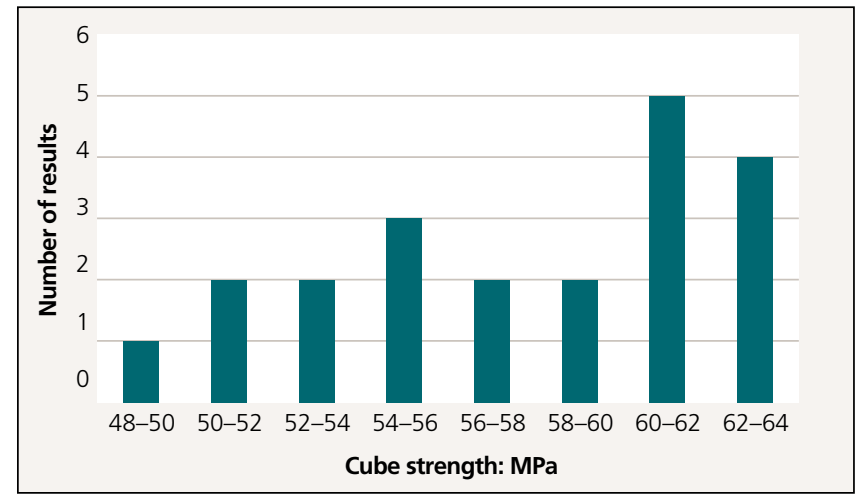

Figure 31. Concrete cube strength tests at 28 days

Colour coding of the reinforcement drawings was effective and the $3 \mathrm{D}$ modelling essential in places to avoid clashes, define the construction sequence and avoid gaps in the reinforcement.

Outline design of temporary works supporting the heavy weight of top reinforcement and appropriate assessment of the construction loads was required to specify the required working strength of the void former and therefore the collapse load used in the design of the slab.

Careful planning of the concrete pour from reinforcement detailing through to road closures to give access to a constrained site in the heart of the City of London, the contingency measures for disrupted concrete supply and the control of concrete temperature led to the successful execution of what was at that time Crossrail's largest concrete pour.

\section{Acknowledgements}

The authors would like to acknowledge the collaborative working of all the Crossrail, Mott MacDonald, Bam Nuttall and Kier site teams and those involved in the construction of the base slab, including: Cordek for the bespoke design of the void former, Capita for the detailing of the reinforcement, Hanson for concrete mix design, development and supply, and Camfaud for the concrete pumps.

\section{References}

Bamforth PB (2007) Early-age Thermal Crack Control in Concrete. CIRIA, London, UK, C660.

BSI (2004) BS EN 1997-1: Eurocode 7: Geotechnical design - Part 1: General rules. BSI, London, UK.

BSI (2005) BS EN 1991-1-6: Eurocode 1: Actions on structures - Part 1-6: General actions - Actions during execution. BSI, London, UK.

BSI (2006a) BS EN 1992-3: Eurocode 2 - Design of concrete structures - Part 3: Liquid retaining and containment structures. BSI, London, UK.

BSI (2006b) BS 8500: Concrete - Complementary British Standard to BS EN 206-1 - Part 1: Method of specifying and guidance for the specifier. BSI, London, UK.

BSI (2009) BS EN 13670: Execution of concrete structures. BSI, London, UK.

BSI (2013) BS EN 206: Concrete. Specification, performance, production and conformity. BSI, London, UK.

The Concrete Centre (2011) Specifying Sustainable Concrete Understanding the Role of Constituent Materials. Mineral Products Association, Camberly, UK. 